\title{
THE CIVIL PROVISIONS OF THE HARASSMENT ACT 1997 A WORRYING AREA OF LEGISLATION?
}

Jane Mountfort*

This article presents a critical analysis of the civil provisions of the Harassment Act 1997 and the leading cases interpreting and applying it. In it, the author suggests that, as currently interpreted by the courts, the Act is a potentially oppressive infringement on normal social relations and individual rights in New Zealand. Noting that the purpose of the Act was to remedy a perceived gap in the law relating to stalking, the author questions whether the more innocuous acts of harassment currently being caught by the Act were intended to be so. The article then considers an alternate interpretation of the Act that would require applicants to show a reasonable fear for safety, and other reform options.

\section{INTRODUCTION}

From its drafting and enactment to its implementation over the last two years, the Harassment Act 1997 ("the Act") has received very little academic scrutiny. There are surprisingly few cases to be found regarding the Act and of those, a comparatively small number have been reported. ${ }^{1}$ The Act defines civil and criminal harassment, enabling victims

* This paper was submitted in fulfilment of the LLB(Hons) requirements at Victoria University in 2000.

1 The reported cases are as follows: P v H [1998] DCR 715; C v G [1998] DCR 805; Hope v Cho [1999] DCR 108; Irvine v Edwards [1999] DCR 171; G v B [1999] DCR 400; Police v D [1999] DCR 426; Espinoza v Commissioner of Police [1999] DCR 686; Police v H [1999] DCR 841; H v S [2000] DCR 90; Beadle v Allen [2000] NZFLR 639. The unreported cases are Krija v Police (1 November 1998) Unreported High Court Auckland AP 188/98; Police v Freeth (16 March 1999) Unreported District Court Auckland CRN 8090016610 - 13; Police v Hodgson (6 May 1999) District Court Feilding CRN 9054003296; Smaill v Police (25 June 1999) Unreported High Court Dunedin AP 17/99; Paul v Carbajal (2 August 1999) Unreported High Court Auckland HC 207/98; Bakker v The District Court and Schoobert (4 August 1999) Unreported High Court Hamilton CP 35/99; Durkin v Police (8 September 1999) Unreported High Court Auckland A 106/99; R v D (27 March 2000) Unreported Court of Appeal CA 438/99. 
to apply for restraining orders against their harassers. ${ }^{2}$ In accordance with the criminal harassment provisions, police can also prosecute perpetrators of harassment. ${ }^{3}$ The Act has made a significant change to the existing law. In spite of this, it has been a relatively uncontroversial piece of legislation. However, closer examination of both the wording and the implementation of the Act, indicate its potentially oppressive application. This article will focus on the interpretation and implementation of the civil harassment provisions of the Act. What can be seen is an Act with considerable implications for social relations and individual rights in New Zealand. Although there are strong arguments why the Act should be interpreted in a less oppressive manner than is currently favoured, it becomes clear that the real difficulty is with the plain wording of the legislation. The vagueness and uncertainty of many of the terms used give rise to the potential for oppressive application. The article concludes with a proposal for reform, which while maintaining an adequate level of protection for victims of harassment is more certain and less of an infringement of fundamental freedoms in New Zealand.

\section{THE RELEVANT PROVISIONS OF THE ACT}

\section{A The Definition of Harassment}

This article is primarily concerned with sections 3 and 4 of the Act. These provisions define harassment for the purposes of both the civil and criminal provisions of the Act. The terms used are vague, reflecting the difficulty in defining the concept of harassment. Section 3 reads as follows:

3 Meaning of "harassment" -

(1) For the purposes of this Act, a person harasses another person if he or she engages in a pattern of behaviour that is directed against that other person, being a pattern of behaviour that includes doing any specified act to the other person on at least 2 separate occasions within a period of 12 months.

(2) To avoid any doubt, -

(a) The specified acts required for the purposes of subsection (1) may be the same type of specified act on each separate occasion, or different types of specified acts:

2 Harassment Act 1997, ss 3 and 4.

3 Harassment Act 1997, s 8. 
(b) The specified acts need not be done to the same person on each separate occasion, as long as the pattern of behaviour is directed against the same person.

Harassment, therefore, consists of a "pattern of behaviour" directed against another person. "Against" is not defined and the difficulties this term poses will be discussed later in this essay. A "pattern of behaviour" consists of two specified acts committed by the respondent (or the defendant in the case of criminal harassment) within a period of 12 months. This requirement has not posed significant interpretation difficulties for the New Zealand Courts thus far. However, the definition of what constitutes a specified act, has recently caused difficulty. ${ }^{4}$ Just how the provisions defining a specified act were to be interpreted was the subject of considerable argument in Beadle $v$ Allen. ${ }^{5}$ It is the interpretation eventually favoured by Potter J in that case which poses concern with regard to the scope of the Act. ${ }^{6}$ Section 4(1) reads:

4 Meaning of "specified act" -

(1) For the purposes of this Act, a specified act, in relation to a person, means any of the following acts:

(a) Watching, loitering near, or preventing or hindering access to or from, that person's place of residence, business, employment, or any other place that the person frequents for any purpose:

(b) Following, stopping, of accosting that person:

(c) Entering, or interfering with, property in that person's possession:

(d) Making contact with that person (whether by telephone, correspondence, or in any way):

(e) Giving offensive material to that person, of leaving it where it will be found by, given to, or brought to the attention of, that person:

(f) Acting in any other way -

(i) That causes that other person ("person A") to fear for his or her safety; and

4 See Beadle v Allen [2000] NZFLR 639 (HC) paras 10 -12.

5 Beadle $v$ Allen, above $\mathrm{n} 4$.

6 Beadle v Allen, above n 4, para 19. 


\section{B The Interpretation Currently Favoured in the New Zealand Courts}

In Beadle $v$ Allenthere was an issue whether the standard specified in section 4(1)(f)(i) and (ii), applies to all the specified acts in section 4, or only to acts that come under paragraph (f). In other words, any act that cannot be fitted in to paragraphs (a) - (e). ${ }^{7}$ At first sight the provision appears clear. On the literal reading, the requirement that the act must cause the person to reasonably fear for his or her personal safety applies only to those acts that come within paragraph (f). Therefore, if the specified act relied upon is a letter sent by the alleged harasser to the other person, it can be brought within paragraph (d) and therefore is not subject to the extra requirement in (f)(i) and (ii). Yet if the specified act relied upon is, for example, the alleged harasser banging on the applicant's door, or pretending to try and run the applicant over at a pedestrian crossing, then it probably cannot be brought within any of the paragraphs (a) - (e). ${ }^{8}$ It can only be brought under paragraph (f), "any other act", and must cause the applicant to fear for his or her personal safety. That act must also be likely to cause a reasonable person in person A's particular circumstances to fear for their personal safety.

\section{Implications of the Current Interpretation of Section 4}

The implications of the literal interpretation are surprisingly far-reaching. Harassment will potentially occur if I post two letters to another person within a period of twelve months. The act of posting a letter comes within paragraph (d). Therefore, on the literal reading, it need not cause that other person to fear for their personal safety. The requirement of two specified acts within the period is satisfied. The only apparent qualification to this requirement is that the specified acts must be "directed against" the other person". These terms are in themselves extremely vague. Furthermore they have not been defined in the Act. Exactly what is required by these terms appears to be a matter for the courts to decide, leaving significant discretion to

each individual court. Perhaps some examples of the type of behaviour the Act might be concerned with would illuminate the matter. Clearly, amicable letters between friends would not be caught. Despite the vagueness of "directed against", it is probably safe to say that this

7 Beadle v Allen, above n 4, paras 11 - 27.

8 However, some may wish to argue that banging on someone's door could come within section 4(1)(c) entering, or interfering with, property in that person's possession, as trespass orders have been issued in such situations, see $D v B$ (1996) 14 FRNZ 617 (Family Court). 
situation is not within the meaning intended by the term. What, however, would the position be, if the recipient of the letters had previously expressed a wish to terminate the friendship and the correspondence, although inoffensive, is unwelcome? Would the situation be more compelling if the letters contained personal insults? The latter mentioned situations could arguably fit within the meaning of the words "directed against". What would the position be, if I telephoned a neighbour on a few occasions to complain about a structure they were erecting on their property, with the potential to diminish my view? This situation could also come within the wording of the provisions. Whether a court would find harassment had occurred in these fact situations, is a matter that cannot be predicted. The applicant must then satisfy the court that the granting of a restraining order is necessary.

\section{$D$ Conditions for the Granting of a Restraining Order}

\section{Section 16}

In order for the harassment to be subject to a restraining order, the court must be satisfied that it passes the test in section 16 . Section 16 reads:

16 Power to make a restraining order -

(1) Subject to section 17, the Court may make a restraining order if it is satisfied that -

(a) The respondent has harassed, or is harassing, the applicant; and

(b) The following requirements are met:

(i) The behaviour in respect of which the application is made causes the applicant distress, or threatens to cause the applicant distress; and

(ii) That behaviour would cause distress, or would threaten to cause distress, to a reasonable person in the applicant's particular circumstances; and

(iii) In all the circumstances, the degree of distress caused or threatened by that behaviour justifies the making of an order; and

(iv) The making of a restraining order is necessary to protect the applicant from further harassment. 


\section{Implications of section 16}

Potter $\mathrm{J}$ in Beadle $v$ Allen reasoned that the inclusion of the qualifying ingredient for the granting of a restraining order of "distress" meant that innocent activities would not be caught by the Act. ${ }^{9}$ Therefore, the absence of qualifications in paragraphs (a) - (e) was of no real consequence. The Act therefore did not risk infringing on individual freedoms. The validity of this claim depends entirely on each individual judge's interpretation of the word "distress". "Distress is a decidedly vague term, capable of describing a broad range of mental states from mildly annoyed to extremely upset. The Concise Oxford Dictionary defines "distress" as: ${ }^{10}$

n. 1 severe pain, sorrow, anguish, etc. 2 the lack of money or comforts... 4 breathlessness; exhaustion.

v.tr. 1 subject to distress; exhaust, afflict. 2 cause anxiety to; make unhappy; vex.

This does little to assist a court wishing to clarify the term, indicating the wide range of mental states which "distress" can be used to describe. Perhaps some ordinary usage examples would illuminate the matter further.

"The victim's family were distressed to learn of the young man's death".

This clearly conveys a completely different meaning from the next example.

"I became quite distressed when my eftpos transaction was declined"

It is not unusual to find the word "distress" used frequently in both of these senses in ordinary language. The examples demonstrate that the word distressed can be used in widely differing senses. The level of protection the Act provides depends entirely on how each individual court interprets the word. The degree to which the Act impacts upon freedom of expression is also dependent on this interpretation. We can therefore respectfully call into question Potter J's assumption that section 16 provides a safeguard on fundamental freedoms.

It appears more than arguable that the purpose of section 16 was to ensure that restraining orders are only granted when an order is necessary to prevent the applicant from further harassment, rather than to prescribe the overall level of conduct required. The behaviour must

9 Beadle v Allen, above n 4, paras 19, 28, 33 - 34 .

10 Della Thompson (ed) The Concise Oxford Dictionary (9 ed, Clarendon Press, Oxford, 1995). 
be causing or threatening to cause distress, but it is assumed that harassment has already been found.

\section{APPLICATIONS OF THE HARASSMENT ACT}

In order to understand just how wide these provisions are, it is necessary to look at the Harassment Act in practice. As previously mentioned, there are few cases demonstrating the application of the civil provisions of the Act. The most important for the purposes of this article is the High Court decision of Beadle $v$ Allen. ${ }^{11}$

\section{A Beadle v Allen}

In the case of Beadle $v$ Allen, a doctor had obtained a restraining order against a former patient in the District Court. ${ }^{12}$ The female patient had written letters and faxes to him and the authorities persistently. ${ }^{13}$ In these letters she accused the doctor of inappropriate behaviour towards her and misdiagnosis of her condition. ${ }^{14}$ Potter $\mathrm{J}$ held that this was clearly "distressing" to the victim within section 16 and that that would have caused a reasonable person in the applicant's particular circumstances to feel distressed. It was not necessary that the behaviour of the respondent caused the applicant to reasonably fear for his personal safety, as the specified acts relied upon fitted clearly within section $4(1)(\mathrm{d})$ and (e). With the exception of small variations, Potter J upheld the restraining order of the District Court.

\section{B $\mathrm{Hv} \mathrm{S}^{15}$}

In the case of $H v S,{ }^{16}$ decided soon after Beadle $v$ Allen, Judge $C \mathrm{R}$ Joyce QC expressed the view that the qualifications in s $4(1)(\mathrm{f})(\mathrm{i})$ and (ii) did not apply to the acts in (a) to (e). ${ }^{17}$ However, it was acknowledged that the interpretation of section 4 was an issue. ${ }^{18}$ The

11 Beadle $v$ Allen above $\mathrm{n} 4$.

12 Beadle v Allen, above n 4, para 3.

13 Beadle $v$ Allen, above $\mathrm{n} 4$, paras 5 - 7.

14 Beadle v Allen, above n 4, paras 5 - 6.

15 HvS [2000] DCR 90.

16 Hv S, above $\mathrm{n} 15$.

$17 H v S$, above n 15, 93.

$18 H v S$, above n 15, 93. 
applicant and the respondent were neighbours. ${ }^{19}$ A restraining order was granted for a pattern of behaviour, which consisted of three specified acts, which were as follows:

(1) Five or so letters written by the defendant to the plaintiff's solicitor or counsel.

(2) The defendant's conduct at a Disputes Tribunal Hearing, which involved the defendant trying to wrestle files from the plaintiff

(3) Continued interference with the sale of the plaintiff's property. ${ }^{20}$

The judge said: 21

There may be a question as to the relationship of subsections (1)(a) - (e) of s 4. It seems to me clear that the content of (a) - (e) makes it plain that the described activities are in themselves sufficient as specified acts.

The judge also held that section 4 (1)(e), "giving offensive material to the other person", was not to be construed narrowly. ${ }^{22}$ The word offensive included "aggressiveness, hurtfulness, that annoys or insults". ${ }^{23}$ This interpretation makes the requirement of harassment even easier for the applicant to satisfy, enabling a great deal of day to day correspondence to potentially be included within the paragraph. For example, leaflets are regularly handed out on New Zealand streets espousing certain religious beliefs, which without doubt "annoy" a great number of people. Circulars deposited in letterboxes are also very "annoying" and certainly persistent. These are activities that we expect people to tolerate in a democratic society. They may be annoying and persistent, yet we would not seriously describe these acts as harassment. Of course a restraining order cannot be granted unless the behaviour is "distressing". The vagueness of this term has already been discussed and the potential for injustice which could result.

$19 H v S$, above $\mathrm{n} 15,90$.

$20 H v S$, above $\mathrm{n} 15,90-91$.

$21 H v S$, above $\mathrm{n} 15,93$.

$22 H v S$, above $\mathrm{n} 15,93$.

$23 H v S$, above $\mathrm{n} 15,93$. 


\section{C $\quad \mathbf{R}$ v D $\mathbf{D}^{24}$}

$R v D$ was an appeal of a criminal conviction for harassment under section 8 of the Act. ${ }^{25}$ The Court of Appeal overturned the conviction on the grounds that the requisite intent for the criminal offence had not been proven. ${ }^{26}$ Although the behaviour caused the victim to fear for her personal safety, the defendant had not intended that result or known that it was likely to occur. $^{27}$ The Court of Appeal did not consider the Harassment Act to pose significant interpretation difficulties either and did not express a final view on the interpretation of section 4. ${ }^{28}$ However, the Court said, "Since s $4(1)(\mathrm{f})$ is a provision designed to catch unusual acts outside the categories identified in s $4(1)(\mathrm{a})$ - (e), some qualitative restriction (as is provided by the reasonable person test) was clearly thought by Parliament to be necessary." 29 Despite this clear statement from the Court, $R v D^{30}$ was a criminal harassment case in which the Court did not need to decide the question of the interpretation of section 4 . Nor did the Court have the opportunity to consider the more extended argument presented in Beadle $v$ Allen. ${ }^{31}$

\section{D $\quad \mathbf{P} \mathbf{v} \mathbf{H}^{32}$}

In $P v H$ the applicant alleged five specified acts, all letters sent to her by the respondent from prison. ${ }^{33}$ The applicant and respondent had previously been in a relationship and none of

$24 R v D$ (27 March 2000) Unreported Court of Appeal CA 438-99.

$25 R v D$, above $\mathrm{n} 24,2$. The facts of that case concerned unwelcome advances by a woman towards a female friend. The recipient interpreted one specified act in particular as a threat of rape. The appellant was charged with criminal harassment under the Act. Although the Act had caused the recipient to fear for her personal safety, the appellant had neither intended nor known it was likely to cause her to fear for her personal safety. The Court of Appeal held that either intention or recklessness was necessary for the criminal offence.

$26 R v D$, above $\mathrm{n} 24,18-19$.

$27 R v D$, above $\mathrm{n} 24,18-20$.

$28 R v D$, above $n 24,7$.

$29 R v D$, above $\mathrm{n} 24,7$.

$30 \quad R v D$ above $n 24$.

31 Beadle v Allen, above $\mathrm{n} 4$.

$32 \quad P v H[1998]$ DCR 715.

$33 P v H$, above $\mathrm{n} 32,719$. 
the letters were of an offensive nature and in fact were quite the opposite. ${ }^{34}$ However, it was held that the letters amounted to a pattern of behaviour, the letters being specified acts under paragraph (d) - Making contact with that person (whether by telephone, correspondence, or in any other way). ${ }^{35}$ The judge appeared to accept the evidence of the applicant that she feared for her personal safety, because of a previous letter sent to the applicant by the appellant after the breakup of the relationship and prior to the twelve-month period. ${ }^{36}$ That letter was particularly offensive, the respondent insinuating that the applicant, who had already lost the use of one hand in an accident, would have the other hand cut off. ${ }^{37}$ The respondent had since apologised for the letter and the applicant appeared to accept that. ${ }^{38}$ However, the Judge accepted that this prior threat led to the subsequent letters causing the applicant to reasonably fear for her personal safety. ${ }^{39}$ The applicant said that the letters were annoying and irritating. Finally she said that the reason why she was so upset about the letters was that she had never got over the initial letter from October 1996 and that it played on her mind all the time. ${ }^{40}$ Despite an apparent acceptance that the letters caused the applicant to fear for her personal safety, the Judge expressed no view as to whether that was in fact necessary for a specified act to be made out. ${ }^{41}$ It is worth noting that although the respondent said that he was happy to cease contact with the applicant, a restraining order was granted, the conditions of section 16 being in the Judge's view clearly satisfied. ${ }^{42}$

$34 \quad P$ v $H$, above n 32, 719.

$35 P v H$, above n 32, 720.

$36 P v H$, above $\mathrm{n} 32,720$.

$37 P v H$, above $\mathrm{n} 32,719$.

$38 \quad P v H$, above $\mathrm{n} 32,719$.

$39 P v H$, above $\mathrm{n} 32,720$.

$40 \quad P v H$, above n 32, 719.

$41 P v H$, above $\mathrm{n} 32,719-720$.

$42 P v H$, above n 32, $720-721$. 


\section{E $\quad \mathrm{Cv} \mathrm{G}^{43}$}

In $C v G$ the application for a restraining order was declined. As in $P v H,{ }^{44}$ a prior incident had occurred which affected the impact of the alleged specified acts. ${ }^{45}$ On a prior occasion, the respondent had assaulted the applicant by punching her in the face. ${ }^{46}$ The applicant alleged that this caused her to feel threatened by a subsequent pattern of behaviour consisting of two alleged specified acts. ${ }^{47}$ The first act concerned an incident at a party where the respondent had glared at the applicant in "an intimidating matter". ${ }^{4}$ The second incident occurred at the District Court hearing for the original assault on the applicant. ${ }^{49}$ The respondent standing in the dock allegedly turned around to face the applicant and "nodded in a knowing and intimidating manner" at the applicant. ${ }^{50}$ The applicant said that because of the previous assault these acts caused the applicant to feel threatened. ${ }^{51}$ The judge dismissed the application, on the grounds that the acts could only be fitted into paragraph (f). ${ }^{52}$ Therefore it was necessary for the acts to cause the applicant to fear for her personal safety and that the acts would have caused a reasonable person, in the particular circumstances of the applicant, to fear for her personal safety. ${ }^{53}$ The Judge held that although the first requirement may have been satisfied, the acts would not have caused a reasonable person to fear for his or her personal safety. ${ }^{54}$ The Judge also had this to say: ${ }^{55}$

43 C v G [1998] DCR 805.

$44 \quad P v H$, above n 32.

$45 \mathrm{C} v \mathrm{G}$, above n 43, $806-807$.

46 C v G, above n $43,806-807$.

47 C v $\mathrm{G}$, above $\mathrm{n} 43,807$.

$48 \quad C v \mathrm{G}$, above $\mathrm{n} 43,807$.

$49 C v \mathrm{G}$, above n $43,807$.

$50 \quad C v G$, above $\mathrm{n} 43,807$.

$51 C v \mathrm{G}$, above n 43,807 .

$52 C v \mathrm{G}$, above $\mathrm{n} 43,807$.

53 C v G, above $\mathrm{n} 43,807$.

$54 C v \mathrm{G}$, above $\mathrm{n} 43,808$.

$55 C v G$, above $\mathrm{n} 43,808$. Section 6 reads: "Object - (1)(b) - ensuring that there is adequate legal protection for all victims of harassment". 
The Harassment Act and in particular the provision relating to the issuing of restraining orders, must be interpreted with a degree of common sense. The object set out in section 6(1)(b) of ensuring that there is adequate legal protection for all victims of harassment will not be advanced by the making of restraining orders in cases where two parties exchange angry glances because of ill feeling between them.

It is interesting that the Judge did not consider that such behaviour would cause a reasonable person, in the particular circumstances of the applicant, to fear for his or her personal safety. The applicant had been previously subject to actual violence by the respondent. Surprisingly, that was not considered enough to cause the applicant to reasonably fear for her personal safety when subjected to threatening glances. This aside, the fact that the specified acts could not be fitted into any of paragraphs (a) - (e) appears to have been the main problem for the applicant. Had she been able to show the glances constituted "making contact with", in (d), then she would not have had to show that they would have caused a reasonable person to fear for personal safety. In $P v H$ non- threatening letters were enough to constitute harassment, because of previous threats. ${ }^{56}$ These two cases show how the act can lead to different results, on what would appear similar facts.

\section{F $\quad G \mathbf{v} B^{57}$}

The case of $G v B$ is an example of a fact situation which it is unlikely the Act was intended to catch. The applicant, who had previously been good friends with the respondent, alleged two specified acts. ${ }^{58}$ The applicant had just been acquitted on charges of child sexual abuse; however, the respondent still believed that the applicant had committed the abuse, allegedly calling the applicant a "child rapist" on two occasions. ${ }^{59}$ The first incident occurred when the applicant telephoned the respondent. ${ }^{60}$ The second occurred in a crowded supermarket, where the respondent allegedly called the applicant a child rapist in a loud aggressive manner, being

$56 P v H$, above $\mathrm{n} 32,720$.

57 G v B [1999] DCR 400.

$58 \quad G v B$, above $\mathrm{n} 57,401$.

$59 G v B$, above $\mathrm{n} 57,401$.

$60 G v B$, above n $57,401$. 
overheard by those present, including the applicant's children. ${ }^{61}$ The Judge said that the Act required: 62

some positive and initiating action on [the part of] a respondent... The whole rationale of the Act was to discourage persons who actively sought out another to "harass" them. A Court should tread carefully before restraining a person from expressing an opinion, however wrong, particularly when the statement was made in a private telephone conversation to the face of the party being criticised. In such situations an applicant retains a remedy in the law of defamation.

The applicant alleged that prior knowledge of the respondent's violent temperament led the acts to cause the applicant to fear for the safety of himself and his family. ${ }^{63}$ However, most would agree that this was not the sort of situation in which we would wish the law to intervene. However, on Potter J's interpretation, the situation is arguably not excluded by the Act. If the acts can be fitted in to paragraph (d), then they need only cause the applicant distress to such an extent, as the Court feels fit. As previously discussed, "distressed" is such a vague term that it gives rise to great deal of uncertainty.

\section{G Conclusion on the Cases}

The cases demonstrate the vastly differing fact situations to which the Harassment Act can apply and its potential to impact upon the social interactions of New Zealanders. In certain instances this application is significantly influenced by each individual judge's view of what is acceptable and unacceptable behaviour, perhaps more so than by a strict application of the wording of the Act.

\section{THE PURPOSE OF THE ACT}

\section{A The Harassment and Criminal Associations Bill}

\section{The purpose of the Bill}

The Harassment Act 1997 went through Parliament as part of the Harassment and Criminal Associations Bill in 1997. The impetus for the legislation came primarily from growing police

$61 G v B$, above $\mathrm{n} 57,401$.

$62 \mathrm{G} v \mathrm{~B}$, above $\mathrm{n} 57,402$.

$63 G v B$, above $\mathrm{n} 57,401$. 
and public concern about gang activity in New Zealand. ${ }^{64}$ The general policy statement in the explanatory note to the Harassment and Criminal Associations Bill was "a package of measures that aims to provide better protection to victims of harassment generally and to place restrictions on the activity of criminal associations or gangs". 65 The last sentence of the general statement highlights the pervasive concern behind the Bill; " The common theme underlying all parts of the Bill is that, although most measures are of general application, they are of particular significance in addressing concerns about gang behaviour". 66 This is indicative of the general mood behind all the provisions including the harassment provisions. ${ }^{67}$ There is a certain level of violence implicit when talking about gang activity, indicating the level of activity the harassment provisions were intended to combat. The introduction to the harassment provisions in the explanatory material to the Bill also provides indications that the provisions are to address a high degree of harassment. ${ }^{68}$ The introduction said "Parts I to IV (now the Harassment Act) seek to provide greater protection for victims of on-going and persistent harassment, commonly referred to by the media as 'stalking'". 69 The policy statements of the Ministry of Justice also continually equate harassment with stalking and in fact use the terms interchangeably. ${ }^{70}$ If stalking and harassment were seen as synonymous, it does somewhat affect was meant by the concept of harassment. When one thinks of stalking, one has visions of obsessive behaviour on the part of the perpetrator, with the effect of causing the victim to fear for their safety and/or being significantly detrimental to the victim's enjoyment of life. If this was the sort of behaviour that Parliament was intending to target, the interpretation of harassment which the New Zealand Courts appear to be applying goes much

64 Harassment and Criminal Associations Bill 1997, no 215-1 ii (the select committee reports); Justice and Law Reform Select Committee "Harassment and Criminal Associations Bill Explanatory Material" i - ii.

65 "Harassment and Criminal Associations Bill Explanatory Material", above n 64, i.

66 "Harassment and Criminal Associations Bill Explanatory Material", above n 64, i.

67 See the policy papers of the Ministry of Justice which reiterate this point, saying, "The common theme underlying all parts of the Bill is that, while most measures are general ones that will apply to specified conduct irrespective of any gang connection, they will have a particular impact on gangs because of the kind of activities, and level of offending, in which they engage." New Zealand Ministry of Justice Harassment and Criminal Associations Bill Further Issues Relating to Provisions on Harassment (CL 18/1 jh964cri, 24 September 1997) 4.

68 "Harassment and Criminal Associations Bill Explanatory Material", above n 64, v.

69 "Harassment and Criminal Associations Bill Explanatory Material", above n 64, v.

70 Further Issues Relating to Provisions on Harassment, above n 67, 1, 3, 4. 
further. The explanatory material to the Bill talks about harassment being behaviour that is "threatening, intimidating or distressing" to the victim. ${ }^{71}$

\section{No report under section 7 of the Bill of Rights Act 1990}

Although the gang concern was unsubstantiated by empirical evidence or detailed study, Parliament passed the Bill, which gave police extensive powers to target "gang" activity in New Zealand. ${ }^{72}$ Despite the obvious impact on civil liberties, the Bill was never subject to a report under section 7 of the New Zealand Bill of Rights Act. ${ }^{73}$ This was in the face of such a recommendation in the submission of the Human Rights Commission on the Bill. ${ }^{74}$ Section 7 of that Act requires the Attorney General to report on the compatibility of legislation with the rights guaranteed by the Bill of Rights Act. Despite this the Ministry of Justice said, ${ }^{75}$

Care was taken when drafting the bill to ensure that it complied with the New Zealand Bill of Rights Act, and thus also with its obligations under international law, in particular the International Covenant on Civil and Political Rights...No such [section 7] report was made at the time this Bill was introduced. Accordingly, the provisions currently in the bill appear to meet the necessary standard.

It possible that had the harassment provisions undergone section 7 report, they may not have been found to be consistent with the rights and freedoms in the Bill of Rights Act.

\section{Submissions to the Select Committee on the harassment provisions}

Because the harassment provisions were included as part of the larger Bill, they received relatively little individual attention at the select committee stage. ${ }^{76}$ This meant the general

71 "Harassment and Criminal Associations Bill Explanatory Material", above n 64, v.

72 Further Issues Relating to Provisions on Harassment, above n 67, 3.

73 Further Issues Relating to Provisions on Harassment, above n 67, 5.

74 Human Rights Commission "Submission to the Justice and Law Reform Select Committee on the Harassment and Criminal Associations Bill" 2.

75 Further Issues Relating to Provisions on Harassment, above n 67, 5.

76 Of 18 submissions received on the Bill, only six specifically addressed the harassment provisions. These were; the Submission of the Auckland Council of Civil Liberties; The Report by the Privacy Commissioner to the Ministry of Justice on the Harassment and Criminal Associations Bill (other than provisions dealing with interception warrants); Submission of the Commonwealth Press Union; Submission of Lynhurst Hospital, Healthlink South; Submission of the Abortion Law Reform Association of New Zealand; Report of the Legislation Advisory Committee. 
application of the harassment provisions did not receive the degree of analysis that could usually be expected for legislation significantly altering existing law. With the exception of the submission of the Auckland Council of Civil Liberties, the submissions did not raise serious concerns about the potential for the harassment provisions to infringe rights and freedoms. That submission raised concerns that the vagueness of the definition of harassment could lead to innocent persons being caught by the Act. ${ }^{77}$ The committee said little to address these seemingly valid concerns and no changes were made. ${ }^{78}$ The Report of the Ministry of Justice cited a need to include all possible situations in need of the intervention of the law within the ambit of the Act. ${ }^{79}$ Indeed, the difficulty of framing legislation widely enough to include all possible situations, yet still clear enough to avoid constitutional attack, has been a problem in drafting harassment and stalking laws in other jurisdictions.

\section{B The Object of the Act}

As in other Common Law jurisdictions, the statutory provision of a law on harassment was based on a perception that the existing law did not provide adequate protection for victims of the behaviour referred to in the policy papers as harassment or stalking. ${ }^{80}$ There were measures available to assist victims in certain instances, for example personal actions based on torts such as private nuisance, but these were seen as inadequate. ${ }^{81}$ This policy objective can be

77 Auckland Council of Civil Liberties (Inc) "Submission to the Justice and Law Reform Committee on the Harassment and Criminal Associations Bill 1997".

78 Harassment and Criminal Associations Bill 1997, no 215 - 2 iii-iv (the select committee report), above $n$ 66, iii - iv.

79 Ministry of Justice "Report on the Harassment and Criminal Associations Bill" (CL 17/01 jh945cri 21, 17 June 1997).

80 "Harassment and Criminal Associations Bill Explanatory Material" above n 64, v.

81 Further Issues Relating to Provisions on Harassment, above n 67, 2 - 3. The Ministry of Justice cited various existing remedies in their reports, these included injunctions, relying on torts such as private nuisance, invasion of privacy and intentional infliction of emotional distress, and said, "such proceedings are likely to be expensive and complex". Also mentioned were a bond to keep the peace under the Summary Proceedings Act 1957, a notice under the Trespass Act 1980, and proceedings under the Human Rights Act 1993 and the Privacy Act 1993. It is also interesting to note that, in Britain it is strongly arguable that a tort of harassment had emerged by the time the Protection from Harassment Act (UK) was passed in 1997. That Act, which has very similar wording to the New Zealand Harassment Act, enables police to take actions against perpetrators of Harassment, instead of individuals having to take a personal action in order to get the protection of the law. It also extended the definition of the kind of behaviour which could be subject to the intervention of the law. The case law prior to the Act showed actual psychological distress suffered by the plaintiff was required. See 
found stated clearly in section 6(1)(b) of the Act itself. These are directions that the court is to be guided by the stated directions when applying the Act. Section 6 reads as follows:

1 Object -

(1) The object of this Act is to provide greater protection to victims of harassment by-

(a) Recognising that behaviour that may appear innocent and trivial when viewed in isolation may amount to harassment when viewed in context; and

(b) Ensuring that there is adequate legal protection for all victims of harassment.

(2) This Act aims to achieve its object by -

(a) Making the most serious types of harassment criminal offences:

(b) Empowering the court to make orders to protect victims of harassment who are not covered by domestic violence legislation:

(c) Providing effective sanctions for breaches of the criminal and civil law relating to harassment.

(3) Any court which, or any person who, exercises any power conferred by or under this Act must be guided in the exercise of that power by the object specified in subsection (1).

\section{Relationship to the Domestic Violence Act 1995}

Most interesting is the statement that the Act is to provide protection for victims of harassment not covered by the domestic violence legislation. The Domestic Violence Act 1995 provides for the granting of restraining orders for domestic violence, including harassment. ${ }^{82}$ Domestic violence as defined in section 3 of that Act includes -

(a) Physical abuse;

(b) Sexual abuse;

Tim Lawson-Cruttenden and Basharat Hussain "Psychological assault and harassment" (1996) 146 New LJ 1326.

82 Domestic Violence Act 1995, s 14. 
(c) Psychological abuse including but not limited to -

(i) Intimidation;

(ii) Harassment;

(iii)Damage to property;

(iv) Threats of psychological abuse, sexual abuse...

\section{Deficiencies of the Domestic Violence Act 1995}

The difficulty is that to be brought under the Domestic Violence Act, the applicant must be in a "domestic relationship" with the abuser. ${ }^{83}$ This meant that victims of harassment who were not in a relationship with the harasser could not use the Domestic Violence Act for protection, nor was there any other legislation for them to rely upon. This deficiency led to a number of cases in which the applicant was unable to obtain protection from the harassment they experienced because they could not show that they were in a "domestic relationship" with the harasser. ${ }^{84}$ Although "harassment" for the purposes of the Domestic Violence Act had clearly occurred, the victim was left without remedy. ${ }^{85}$ The object stated in section 6 of the Harassment Act was a reflection that the Act was designed to protect such applicants. ${ }^{86}$

\section{The relationship between the Domestic Violence Act and the Harassment Act}

The policy statements of the Ministry of Justice regarding the Harassment Act provide further indication of the relationship intended between the two Acts.

83 Domestic Violence Act 1995, s 4(1)(b).

84 Two such cases were $D$ v B (1996) 14 FRNZ 617; [1996] NZFLR 812 (Family Court), and Willeman v Maney [1997] NZFLR 280 (DC). The applicants in both cases could not show that they were in a "close personal relationship" with the respondent, within s 4(1)(d) of the Domestic Violence Act 1995.

$85 D v B$, above $\mathrm{n} 84$, and Willeman $v$ Maney, above $\mathrm{n} 84$. As Judge B D Inglis QC in B v D noted, "that Act [the Harassment Act] appears to have been designed to avoid the difficulties in applying the Domestic Violence Act referred to in cases such as D v B (1996) 14 FRNZ 617".

86 "Harassment and Criminal Associations Bill Explanatory Material", above n 64, v. See also the statement of 28 April 1997 which recognises that the existing law does not adequately protect victims of harassment and points out that"[i]n the civil context, the Domestic Violence Act 1995 contains a regime that protects against harassment in domestic relationships. The lack of an adequate civil remedy, for victims who do not have such a relationship with the harasser, was identified in submissions on that Bill as an issue in need of further consideration". 
The report said,"[persons] covered by domestic violence legislation cannot apply for an order [under the Harassment Act] but should instead use that regime." ${ }^{17}$ Under section 9(4) of the Act, an applicant who is subject to the domestic violence regime, cannot avail themselves to protection under the Harassment Act. In Dudley v Brooks, Giles J reiterated the complementary relationship intended by Parliament between the Domestic Violence Act and the Harassment Act. $^{88}$ In declining an application for a protection order under the Domestic Violence Act, because no domestic relationship could be shown, his Honour said that the applicant was not without a remedy. He added that the Act "was designed to protect the very people who could not be brought within the framework of the Domestic Violence Act". 89

\section{Are the two regimes in fact complementary?}

If the two regimes were designed to be complementary, it seems unlikely that Parliament intended a lesser degree of protection to be available to those in domestic relationships with their harassers. The problem is that both the wording and the subsequent implementation of the Harassment Act go much further than the Domestic Violence Act. The Domestic Violence Act requires psychological abuse (see section 3(2)(c)(i) above), ${ }^{90}$ which suggests a very serious level of conduct. In others words the Harassment Act permits a much lower level of harassment before the law will intervene than the Domestic Violence Act appears to. ${ }^{91}$ Although the Domestic Violence Act does not define harassment, the jurisprudence indicates a serious level of conduct is required. Potter J in Beadle v Allen said, ${ }^{92}$

The [Harassment] Act then, aims to regulate harassment within social relationships generally. It has a broader ambit than the Domestic Violence Act...harassment under the Act may but need not, harm or put at risk physical or mental well-being (unless the specified act relied on is under [section] 4(1)(f). It is not limited, as is harassment in [section] 3 of the Domestic Violence Act to situations of psychological abuse. Harassment under the Act is a concept and has a meaning more embracing and more benign, than domestic violence under the Domestic Violence Act.

87 "Report on the Harassment and Criminal Associations Bill", above n 79, 11.

88 Dudley v Brooks (1998) 17 FRNZ 612, 634.

89 Dudleyv Brooks, above n 90, 634.

90 Domestic Violence Act 1995, s 3(2)(c)(i).

91 See also Hooker $v$ Austin [1997] NZFLR 588, 591 (Family Court).

92 Beadle v Allen, above n 4, para 18. 
It appears an applicant who is in a "domestic relationship" with the harasser must show a more serious form of conduct on the part of the alleged harasser, to receive the protection of the court. Any justification for this distinction is less than evident. Indeed, counsel for the respondent in Beadle $v$ Allen argued the questionable logic of this distinction (especially in light of the object set out in section 6 of the Act). ${ }^{93}$ However, with respect, her Honour did not offer any policy explanation for the higher degree of protection accorded to those outside domestic relationships on her interpretation of section 4 . With respect, such an interpretation could be interpreted as downplaying the serious nature of domestic violence. Surely this is the opposite of what the government intended to achieve with the reformed 1995 Act, in which psychological abuse was included within the definition of domestic violence. ${ }^{94}$ On the other hand, if Potter J is correct and the Harassment Act was intended to provide a greater level of protection, it might make sense that those in some forms of domestic relationships could not rely upon that greater level of protection. Considering the usual nature of many domestic relationships, the consequence would likely be an unmanageable volume of restraining orders.

\section{ARGUMENTS FOR AN ALTERNATIVE INTERPRETATION}

Arguments can be made that, with respect, Potter J simply got the interpretation of section 4 wrong in Beadle $v$ Allen. ${ }^{95}$ The genesis of the Act and the policy reasons behind it and the objectives stated in the Act all provide an indication of the type of behaviour that the Act was aimed at. Admittedly upon first examination, section 4 seems clear. The criteria in section 4(1)(f)(i) and (ii) do not apply to the activities outlined in paragraphs (a) - (e). Certainly, if they were intended to extend to any specified act, the clause has been very poorly drafted and has the potential to give rise to injustice (and arguably did in Beadle and $\mathrm{H} v \mathrm{~S}$ ).

\section{A Relationship Between Paragraphs (a) - (e) and Paragraph (f)}

First, paragraphs (a) - (e) could be interpreted as a list of examples, included by Parliament to give an indication of the types of acts that can constitute harassment, rather than to make a mutually exclusive list of activities that are of themselves acts of harassment. The major provision is section $4(1)(\mathrm{f})$, containing the main requirement for a specified act. Although any act can potentially be part of a pattern of behaviour constituting harassment, the inclusion of examples is an indicator to the court that activities appearing legal on their face may in fact be

93 Beadle v Allen, above n 4, para 11.

94 (10 October 1995) 551 NZPD 9581 -9584; (12 October 1995) 551 NZPD 9730.

95 Beadle v Allen, above $\mathrm{n} 4$. 
acts of harassment. This serves to strengthen the object set out in section 6. To elevate certain acts above others would be to in effect give victims a level of protection depending on exactly which acts had been directed against them, although the effect of the harassment may have been just as serious. Differentiating some specified acts from others would also be contrary to the purposes of the Act, as specified in section 6(1)(b), to provide adequate legal protection to all victims of harassment. It is the effect of the pattern of behaviour, rather than an analysis of each individual specified act, which is the concern of the Act. To treat the Act otherwise, risks becoming an interpretational nightmare, with protection depending on counsel's ability to convince the court that the alleged acts of harassment come within paragraphs (a) - (e), and not (f), which requires the higher standard. It seems likely that Parliament included paragraph (f) to avoid this very consequence.

\section{B Contextual Indications}

The interpretation suggested above is supported by a number of contextual factors.

\section{Different results for different specified acts}

Section 3 states clearly that:

(1) To avoid any doubt, -

(a) The specified acts required for the purposes of subsection (1) may be the same type of specified act on each separate occasion, or different types of specified acts:

(b) The specified acts need not be done to the same person on each separate occasion, as long as the pattern of behaviour is directed against the same person.

Harassment may occur if a defendant sends a letter to the plaintiff on one occasion within a twelve-month period (paragraph (d)) and on another occasion exchanges words with the applicant in a shop. On Potter J's interpretation the first act need not cause the applicant to reasonably fear for his or her personal safety, or indeed cause any effect at all on the applicant. However, the second specified act must cause the applicant to fear for his or her personal safety, because it can not be included within paragraphs (a) - (e), (unless the applicant can persuade the court that it can be described as "correspondence" within the meaning of paragraph (d)). It seems strange that "harassment" can consist of a combination of different specified acts, yet each of those acts need not elicit the same effect. The only reasonable explanation could be that Parliament considered that some acts are by definition harassment and, it can be assumed, would cause any reasonable person to feel threatened. Certainly, some of the acts listed in paragraphs (a) - (e) could arguably come within such a category and do not 
need further qualification. Preventing or hindering access to or from that person's place of residence would cause a reasonable person to feel threatened. However, other acts, such as corresponding with another person, need further qualification before they can be considered to surpass what we expect people to put up with as part of everyday life. Harassment should be above and beyond the normal activities of everyday human existence. Although the words "directed against" imply some form of harm, they are surely not sufficient qualification to make the required distinction between what one should and should not have to put up with.

\section{Relationship between the Civil and the Criminal Provisions of the Act}

Section 6(2)(b) states that the Act makes the most serious types of harassment criminal harassment. This distinction is relevant to the interpretation of section 4 . A further reason why one would expect the qualifications in section 4(1)(f)(i) and (ii) to apply to all specified acts is because the definition of harassment applies to both civil and criminal harassment. Section $8(1)$ outlines the further requirements for criminal harassment. Section $8(1)$ reads:

(1) Every person commits an offence who harasses another person in any case where-

(a) The first-mentioned person intends that harassment to cause that other person to fear for -

(i) That other person's safety: or

(ii) The safety of any other person with whom that other person is in a family relationship; or

(b) The first-mentioned person knows that the harassment is likely to cause the other person, given his or her particular circumstances, to reasonably fear for -

(i) That other person's safety; or

(ii) The safety of any other person with whom that other person is in a family relationship.

Section 8 appears to be concerned only with the mental state of the accused needed for the criminal offence of harassment, rather than the actus reus of the offence. Indeed the recent Court of Appeal case of $R v D$ held that section 8 related only to the mental state of the accused. ${ }^{96}$ It was necessary for the prosecution to prove that the accused intended the pattern

$96 R v D$, above $\mathrm{n} 24,5$. 
of behaviour to cause the victim to fear for personal safety or knew that that result was likely to occur. The actual effect on the victim was not the relevant inquiry under section 8 . The Court said, "the test in s 8(1)(b) is concerned with the accused's knowledge of the effect likely to be caused." 97 Therefore the actus reus of the offence must be found in sections 3 and 4 . Indeed section 8 assumes that harassment has already been found. However, one would assume that a criminal conviction would involve the harassment actually causing the victim to fear for personal safety. However, if we accept Potter J's interpretation, it appears that the offence could be made out without the behaviour actually causing the "victim" to fear for his or her personal safety. The harassment (actus reus) could consist of as little as two letters sent to the other person within a twelve-month period. The acts, coming within paragraph (d), need not cause the victim to fear for his or her personal safety. If the accused intended that result, or even knew that result was likely to occur, then section 8 would be satisfied and the criminal offence made out. This would appear to be a rather strange result and would normally be viewed as attempted harassment, rather than the full offence. Simester and Brookbanks write, "[w]hile harmful consequences may be a reason in favour of criminalising behaviour, conversely behaviour should not normally be criminalised unless it causes harm." 98 An absence of harm would certainly make the offence of harassment rather unusual among crimes. Perhaps a court would likely imply harm into section 8, to avoid such a result. However, the fact remains that the section on its plain reading, following the interpretation recently favoured by the Court of Appeal, does not require that implication.

\section{WHY POTTER J'S INTERPRETATION WAS PROBABLY CORRECT}

Despite strong arguments why the Act should be interpreted differently, there are a number of strong reasons why Potter J's interpretation appears most likely to be the one intended by Parliament.

\section{A Plain Meaning of the Words}

First, the way section 4 is worded indicates that subparagraphs (i) and (ii) were likely intended to apply only to "any other act". If Parliament had intended the qualifications to apply to all specified acts, it seems very unlikely it would have chosen the wording it did. It is more likely that Parliament would have included those subparagraphs as a separate subsection to be satisfied, rather than as it did, as subparagraphs of paragraph (f).

$97 \quad R v D$, above $\mathrm{n} 24,7$.

98 AP Simester and Warren J Brookbanks Principles of Criminal Law (Brooker's, Wellington, 1998) 8. 


\section{B The Original Draft of Section 4}

Further evidence that Potter J's interpretation was the one intended by Parliament can be found in the original drafts of the section. Clause 4(1)(f) (now section 4) originally read: 99

(f) Acting in any other way that could reasonably cause the other person in his or her particular circumstances to fear for his or her personal safety.

This is strong evidence that Parliament intended to confine subparagraphs (i) and (ii) to acts that could not be brought under the specified acts in paragraphs (a) - (e).

\section{Comments of the Select Committee}

In reviewing submissions that clause 4 was too vague, the Ministry of Justice noted that the list approach was decided upon because "on balance this was considered to be preferable and as providing a reasonable degree of certainty." 100 This was in contrast to the United Kingdom approach of leaving the term "harassment" largely undefined, with the Courts determining it though case law. ${ }^{101}$ The Committee considered this too vague and uncertain, with the potential to infringe the New Zealand Bill of Rights Act 1990, particularly freedom of expression and association. ${ }^{102}$ Submissions suggested that what is now section 4(1)(f) allowed perfectly lawful conduct to come within the ambit of the regime. The Report of the Ministry said, "This paragraph is intended to draw a line between the kind of behaviour that people can be expected to cope with as part of the exigencies of day-to-day life and other behaviour that arguably they should not have to put up with."103 The Report appears to be saying that the acts listed in paragraphs (a) - (e) are not the normal exigencies of everyday life and therefore should not have to be put up with. Although it definitely arguable that someone should not have to put up with being followed or accosted it would be difficult to argue that receiving contact from another person is an activity outside the normal exigencies of everyday life. Following and accosting are by their very nature threatening, but making contact with another person is not. It needs further qualification, before it becomes something that an ordinary

99 "Harassment and Criminal Associations Bill Explanatory Materials", above n 64, vi.

100 "Report on the Harassment and Criminal Associations Bill", above n 79, 20.

101 "Report on the Harassment and Criminal Associations Bill", above n 79, 19.

102 "Report on the Harassment and Criminal Associations Bill", above n 79, 19 - 20.

103 "Report on the Harassment and Criminal Associations Bill", above n 79, 21. 
person cannot be expected to put up with. It seems that through sloppy drafting, the Act has actually captured activities that Parliament intended to exclude.

\section{PROPOSED AMENDMENT}

\section{A Amendment to Section 4}

Because of the vagueness of the wording and the resulting potential for injustice, the writer proposes amending the civil provisions of the Harassment Act. The proposed amendment reads as follows:

3 Meaning of "harassment" -

(1) For the purposes of this Act, a person harasses another person if he or she engages in a pattern of behaviour that is directed against that other person, with the cumulative effect of

(a) causing or threatening to cause that other person to fear for his or her personal safety, and that pattern of behaviour -

(b) would cause or would threaten to cause a reasonable person in the particular circumstances of that other person to fear for his or personal safety; or

(c) is significantly detrimental or threatening to be significantly detrimental to that other person's quality of life; and that pattern of behaviour -

(d) would be significantly detrimental of threaten to be significantly detrimental to the quality of life of a reasonable person in the particular circumstances of the other person.

(2) A pattern of behaviour for the purposes of this act consists of doing at least two specified acts to the other person the within a period of twelve months.

4 Meaning of "specified act" -

(1) For the purposes of this Act, a specified act is any act done by a person to another person, including but not limited to:

(a) Watching, loitering near, or preventing or hindering access to or from, that person's place of residence, business, employment, or any other place that the other person frequents for any purpose;

... [paragraphs $(b)-(d)] \ldots$ 
This would appear to be a much more certain test than that currently contained in the Act. Any law, especially one that impacts upon fundamental freedoms, should be framed with clarity and precision. Legislation should comply with the rule of law, being sufficiently clear so as to enable citizens to regulate their behaviour accordingly. It is then less likely to catch innocent activities, and infringe on civil liberties such as freedom of speech. The alternative drafting also satisfies the objectives in section 6 of the Act. Firstly, it ensures that there is adequate legal protection for all victims of harassment (section 6(1)(b)). By focusing on the cumulative affect of the behaviour rather than each individual act, it recognises that behaviour, which may appear innocent on the surface, may in fact amount to harassment when viewed in context. This also eliminates the need for distracting inquiries into what constitutes a specified act and which category the alleged specified acts fall into. It recognises that an infinite number of behaviours may constitute acts of harassment and that many innocuous activities may amount to harassment when viewed in context (section 6(1)(a)). It is also more in line with the degree of protection for harassment accorded to those in domestic relationships covered by the Domestic Violence Act 1995.

\section{B Required Effect of the Pattern of Behaviour}

It would be too high a standard to require each individual specified act to cause the applicant to reasonably fear for his or her personal safety. It is the cumulative affect of those acts that makes the pattern of behaviour harassment and therefore in need of the protection of the law. The cumulative effect would need to cause the applicant to reasonably fear for his or her personal safety or be significantly detrimental to the other person's enjoyment of life. This gives a higher degree of protection to individual freedoms than the current Act. The inclusion of the latter option (being significantly detrimental to enjoyment of life) is recognition that behaviour may still warrant the intervention of the law, even if it does not cause the applicant to fear for his or her personal safety.

\section{CONCLUSION}

The Harassment Act 1997 was intended by Parliament to fill a gap in the existing law. Passing through Parliament as part of a package of measures to target gang activity in New Zealand, the Act was also intended to be of general application. This genesis appears to have been responsible for an Act which is not only poorly drafted, but has a potential application in excess of Parliament's intention. The vagueness of the terms used has left ordinary citizens 
uncertain as to what kind of behaviour will be caught by the Act and hence lacking the required knowledge to alter their conduct to comply with the law. The Act has the potential to impact on a wide variety of social situations and infringe the values of a democratic society. This cannot only be attributed to the interpretation currently favoured by the New Zealand courts, but to the apparently unambiguous wording of section 4. In order for the Harassment Act to respect the values of a democratic society, it is proposed that the civil provisions of the Act should be amended. This amendment gives full effect to the statutory objects of the legislation, providing adequate protection for victims of harassment. Primarily it aims to uphold the values of a democratic society and provide a law, which is accessible and certain for ordinary New Zealand citizens. 
